Khodachuk Y., Maslova Y. Sexism in the advertising discourse of Ukraine. Journal of Education, Health and Sport. 2021;11(11):207-213. eISSN 2391-8306. DOI http://dx.doi.org/10.12775/JEHS.2021.11.11.020

https://apcz.umk.pl/JEHS/article/view/JEHS.2021.11.11.020

https://zenodo.org/record/5757721

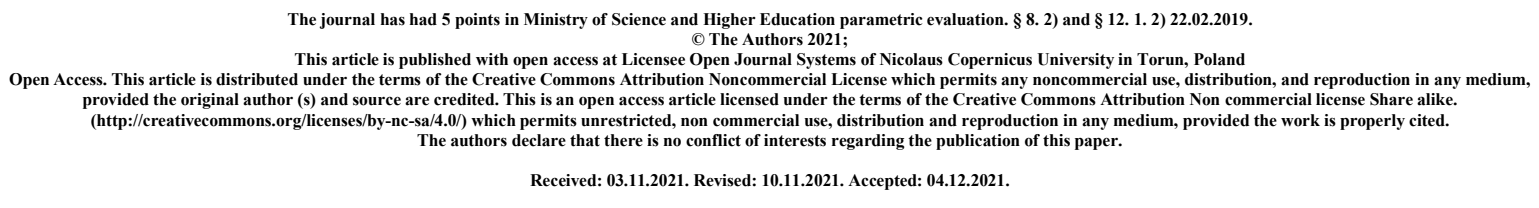

СЕКСИЗМ У ДИСКУРСІ РЕКЛАМИ УКРАЇНИ

Ходачук Яна, Маслова Юлія

Національний університет «Острозька академія»

У статті визначено причини використання сексистської реклами в украйнському медіа дискурсі

та ї̈ вплив на формування жіночого образу та сочіального добробуту. Проаналізовано

сексистські рекламні кампанії украӥнскьких організацій.

Ключові слова: сексизм, реклама, об’єктивація, стереотипізація, медіа

\title{
Sexism in the advertising discourse of Ukraine
}

\section{Y. Khodachuk, Y. Maslova}

National University of Ostroh Academy

Anotation. The article identifies the reasons for the use of sexist advertising in the Ukrainian media discourse and its impact on the formation of women's image and social well-being. Sexist advertising campaigns of Ukrainian organizations are analyzed.

Key words: sexism, advertising, objectification, stereotyping, media

Постановка проблеми. На сьогоднішні реклама посідає одне 3 найважливіших місць у формуванні соціальних норм та цінностей. За допомогою реклами у свідомості споживча закладаються образи та моделі поведінки, які 
продемонстровані у ній, але за часту вони не сходяться з реальністю. Адже головна задача реклами - за короткий період підвищити впізнаваність бренду та збільшити кількість продажів, використовуючи легку для сприйняття рекламу. Для виконання даної задачі неодноразово використовують спрощені стереотипні образи серед чоловіків та жінок.

Поруч 3 даною ситуацією, ще більш актуальною стає проблема сексизму у рекламі. 3 кожним роком приймається все більше заходів, щодо заборони сексистської реклами, але вона досі присутня. Ця реклама сприяє тому, що образ та роль жінки нівелюються у сучасному суспільстві.

Аналіз останніх досліджень. Серед науковців, які активно досліджували негативний вплив сексизму на формування гендерних моделей поведінки у засобах масової інформації слід виокремити: Ю. Маслову, О. Кісь, О. Бучинську та В. Суковату.

Метою статті є детальний розгляд прийому сексуалізації в рекламному дискурсі України та аналіз впливу сексистської реклами на формування жіночих моделей поведінки, гендерної нерівності та ставлення до жінок.

Викладення основного матеріалу дослідження. Сексизм у рекламних матеріалах часто набирає різноманітних форм та видів, які по-різному впливають на споживача, але в загальному вони формують спотворені стереотипні образи та поведінку певних груп (жінок, чоловіків, гомосексуалів і т.п.), завдяки чому знижують їхню роль у сучасному суспільстві та вибудовують нові види гендерної нерівності. Сексизм - це дискримінація та/або нетерпимість до людей на підстав їхньої статті, а не на особистих рисах чи вчинках.[2]

Реклама відіграє важливу роль у становлені гендерних моделей поведінки. Адже саме через рекламу для споживачів транслюються цінності, які виробники закладають у своїй продукції. Важливим показником є те, що реклама також формує нашу культуру та свідомість. Це все впливає на становлення жіночих та чоловічих образів у нашій культурі. Адже важко протистояти тим образам, що тобі активно навіюють 3 самого дитинства. У сексистскій рекламі візуальні сигнали, такі як жести, поза чи вираз обличчя, часто розповідають ще більше про саму рекламу, допомагаючи споживачу завершити повноцінну картину у його голові. 
Серед українських рекламних кампаній часто прослідковується нав'язування одних і тих самих моделей поведінки в конкретних сферах. До прикладу, якщо згадати рекламу миючого засобу для посуди «Fairy», де нам завжди демонстрували застілля щасливої сім’ї і по його закінченню, жінку, яка повинна була перемити безліч посуду. Тобто, що така робота стосується лише жінок, адже на думку компанії, лише вони займаються миттям посуду. А ще у цій рекламі акцентували увагу і на тому, що саме цей засіб береже жіночі ручки і є абсолютно безпечним для жінок. У той же час, коли чоловіків зображали лише як голову сім’ї на застіллі і більше мова про них не йшлася. Тому у рекламі чітко простежуємо стереотипний жіночий образ «Домогосподарки» та «Берегині». Дослідники вважають, що насправді існує зв'язок між зображенням жінок у рекламі та сприйняттям жіночих ролей у суспільстві. Реклама описує, як повинна виглядати жінка та іiі конкретну модель поведінки, що впливає на створення суспільних стандартів і закладених образів. Адже дуже часто можна почути фразу «жінка повинна мити посуд», «місце жінки біля плити» або те, що жінки - погані водії, за словами чоловіків. Це все відбувається тому, що реклами заклали нам такий жіночий образ та стереотип.

Існують різноманітні механізми висвітлення сексизму: шляхом стереотипних зображень жінок, об’єктивації, принизливих та образливих зображень стосовно протилежної статі. [3] Сексуальна об'єктивізація жінок у рекламі пояснюється (виправдовується), тим, що привертає великий відсоток уваги і завдяки цьому товар краще продається, адже грає на первинних істинктах потягу, жаги, бажання. Звісно, що це працює, але де межа? Далі трапляються елементи агресії, руйнування, порнографічних натяків, що порушує норми етики й моралі медійного простору.

Варто зауважити, що сексистська реклама впливає на деформаційне сприйняття свого власного тіла, особливо жінок. Оскільки, для створення такої реклами відбираются відповідні моделі, які здатні викликати емоції у чоловіків. До прикладу, жінки завжди намагаються тримати своє тіло у тонусі і згідно із «всесвітньо відомими» параметрами 90-60-90, адже в рекламах у ролі «ЖінкиКішки», «Барбі» чи «Сексуальної іграшки» демонструюють саме таких жінок. При цьому створюють штучну шкалу краси і заставляють на підсвідомому рівні під неї підлаштовуватися. Часто у рекламі, де показують красивих жінок, 
фокусуються лише на певній частині тіла, автоматично спрямовуючи аудиторію на сфокусовану красу. У гонитві за прекрасним тілом жінки часто забувають про своє фізичне, психологічне та духовне здоров'я, вдаються до булімії та набувають анорексії.

Дослідники виділяють наступні види сексизму в рекламі:

- Об’єктивація жіночого тіла - це репрезентація жінки чи жіночого тіла як частини товару для чоловічої аудиторії споживачів.

- Еротизація - демонстрація оголеного тіла чи частини тіла, відповідної еротичної пози, яка б натякала на інтим чоловікам-споживачам, а також контексту за допомогою яких у чоловіків закріплюється образ підлеглої, беззахисної жінки готової до статевого акту.

- Фейсизм - різноманітні способи зображання жінок і чоловіків. У першому випадку акцентують здебільшого увагу на голові та обличчі, у другому на тілі та його частинах.

- Мачизм - це підкреслення чоловічого домінування над жінками. У даному виді сексистської реклами часто наголошують на традиційних ознак маскулінності.[4]

Яскравим прикладом сексистської реклами $є$ Instagram профіль «Perepichka_1981». У 2018 році з’явився акаунт закладу «Київська перепічка», що славиться свою випічкою, але пости, які публікувалися у даному акаунті привели всіх у шок. Для реклами закладу використовувалася види сексистської реклами, перераховані вище. Цікавим фактом є те, що при зображенні на фотографії жінки, використовували об'єктивізацію, еротизацію та фейсизм. Випічкою прикривали оголені інтимні жіночі частини тіла, супроводжуючи це відповідним текстом. При публікуванні чоловічих зображень із випічкою використовували мачизм. Здебільшого зосереджували увагу на чоловічих м'язах. Це і являється прямою дискримінаційною рекламою. На сьогодні цей аккаунт припинив свою діяльність y Instagram.

Ще одним прикладом сексистської реклами є ряд відеороликів від «Епіцентр К». В першій рекламі «Що таке сад-город?» зображений стереотипний гендерний образ Жінки-Домогосподарки, яка виключно займається городом, а не роботою чи СПА-процедурами. Друга реклама «Будівельний безліміт» зображала дівчат у 
відкритій спортивній формі, які займалися спортом на фоні будівельних товарів, а натовп чоловіків з захопленими очима спостерігав за цим дійством. Даний відеоролик розкритикували, оскільки у ньому присутня об'єктивація жіночого тіла та його еротизація.

Мережа магазинів електроніки «Цитрус» часто дивують своїх клієнтів дискримінаційною рекламою. Наприклад, до жіночого свята 8-го березня, Цитрус випустив ролик на Youtube 3 назвою «Хватить симулювати подарунки», натякаючи на те, що жінки втомилися від стереотипних подарунків (посуду, кашпо, друшляків і т.д.). Аудиторія магазину сприйняла це так, ніби справжній чоловік повинен знати, що на восьме березня жінкам потрібно догоджати. Тут створюється негативний жіночий образ, а також образ слабкого чоловіка, який мислить стереотипно.

Ще одним цікавим прикладом реклами в Цитрус є серія зображень, приурочених виходу нового IPhone. На першій рекламі зображена жінка в характерному образі «Сексуальної іграшки» 3 телефоном марки Apple i дане зображення супроводжується рекламним текстом: «Взяла в кредит, а не те, що ти подумав». На другому фото перед нами постає жінка у еротичному костюмі 3 підписом «Подаруєш яблуко - попариш моркву». Та на третій фотографії зображена протягнута жіноча рука, яка очікує, щоб їй щось положили туди і підписано «Поклади в іï долоньку». Всі ці реклами натякають на те, що цей телефон дістався їй через надання сексуальних послуг або ж навпаки дістанеться, якщо вона буде лагідна 3 чоловіком. Ця реклама є надто сексистською, вона дискримінує жінок і створює легковажний та ще один стереотипний образ. Його зміст в тому, що жінка не може дозволити собі товари цього бренду і лише чоловіки за певні «досягнення» готові купувати їх жінкам.

Прикладом чоловічої дискримінації у рекламі від «Цитрус» виступив постер, приурочений до 8-го березня і на якому зображений оголений чоловік у фартуху, що миє підлогу 3 текстом «Просто не твій день, бро!». Таку рекламу можна розглядати 3 двох сторін. 3 одного боку вона демонструє слабкого чоловіка, який раз на рік перебирає образ Домогосподарки на себе. 3 іншого - натякають на те, що лише один раз в рік чоловік допомагає своїй дружині з побутовими справами. В інші дні вона займається цим сама. 
14 вересня 2021 в Україні відбулося представлення результатів дослідження, яке проводив Фонд ім. Фредріха Еберта на тему ставлення українського населення до дискримінаційної за ознакою статті реклами. [5] Згідно із результатами дослідження більшість опитаних вважають сексистську рекламу «вульгарною» та тією, що «принижує людську гідність». Стало відомо, що 70\% жінок та 50\% чоловіків мають негативне ставлення до нав'язливих гендерних стереотипів у рекламі. Вони стверджують, що сексистська реклама не йшла на користь упізнаваності бренду, а навпаки відволікала від запам'ятовування конкретного бренду. Назва бренду запам'ятовувалася втричі краще, коли аудиторії давали переглянути недискримінаційну рекламу. [6]

10 вересня 2021 року Верховна Рада України прийняла Закон «Про внесення змін до Закону України «Про рекламу» щодо протидії дискримінації за ознакою статті». У новому Законі було визначено поняття «дискримінаційна реклама» та «дискримінаційна реклама за ознакою статті», а також окреслено та посилено права споживачів реклами. За новим Законом у рекламі забороняється демонструвати будь-яку перевагу однієї статі над іншою, стереотипні суспільні моделі поведінки чоловіка та жінки, насильство, що застосовується до кожної зі стать, а також забороняється використовувати рекламу з прямими натяками на секс, якщо вона не стосується продукту. [1]

Висновки. У статті продемонстровано провідну роль реклами у становленні суспільної культури та цінностей, які передаються з покоління в покоління. Тому що, нас усюди оточує реклама: на телебаченні, в соціальних мережах, на радіо, на вулиці та на продуктах, які ми купуємо для себе. Кожен день, користуючись громадським транспортом ми помічаємо безліч зовнішньої реклами в автобусі, вагоні метро, поїзді, машині, а також в літаку. Потрібно визнати, що реклама впливає на все українське населення, незважаючи на вік, стать, расу, культурне походження, соціальний статус, рівень сексуальності.

Ситуація у світі щодо сексистської реклами стабілізується. Все менше і менше трапляється рекламних кампаній, у яких застосовують еротизацію та об’єктивацію. В Україні ситуація складніша. Оскільки, не зважаючи на заборони для такого типу реклами, бренди та організації не звертають уваги на застереження. На жаль, до прийняття цього Закону в українській рекламі уже достатньо багато сексизму, який допоміг сформувати стереотипні образи. Згідно 
iз статистичними даними, 90\% дискримінаційної реклами в Україні стосується жінок. Жіночу сексуальність використовують для підняття цінності продуту та підвищення продажів. Адже рекламодавці, вважають, що чим більше в рекламі продемонструють сексуальну жінку та ще й оголену, то тим більше говоритимуть про їхню компанію чи організацію.

Відтепер, після прийняття нового Закону ситуація на українському ринку повинна змінитися в кращу сторону. Оскільки, сексистська реклама несе у собі пагубний вплив на жінок, а саме на ставлення до них.

Компаніям потрібно одуматися та зрозуміти врешті-решт, що аудиторії набагато цікавіше розглядати нестереотипну рекламу, яка відкриває нові горизонти в формуванні жіночого та чоловічого образів у суспільстві. Потрібно відходити від стереотипних моделей поведінки, адже нове покоління все частіше критикує такі кампанії і вимагає демонструвати натуральність, неідеальність та справжність, тому що саме це підкуповує споживачів, які втомились від ідеальної картинки та гендерної нерівності.

\section{References}

1. Information department of the Staff of the Verkhovna Rada of Ukraine. The Law "On Amendments to the Law of Ukraine "On Advertising" on Combating Sex Discrimination" [Electronic Resource] Information Department of the Staff of the Verkhovna Rada of Ukraine was adopted. 2021. Resource access mode: https://www.rada.gov.ua/news/Novyny/213702.html

2. Kis O. Sexism in the media: countering communicative streaming [Electronic resource] O. Kis. 2007. Resource access mode: https://bit.ly/2ZDBgXp

3. Nelson M

CrossCultural Differences in Sexual Advertising Content in a Transnational Women's. Magazine [Text] M. Nelson, H. Paek. Sex Roles. 2005. Vol. 53, № 5-6.

4. Ladica I. Sexism in online advertising: how to detect and how to fight? [Electronic resource] I. Ladika Media criticism. 2018. Resource access mode: http://www.mediakrytyka.info/za-schokrytykuyut-media/erotyka-ta-pornografia/seksyzm-u-merezheviy-reklami-yak-vyyavyty-i-yakborotysya.html

5. Presentation "Study of the attitude of the population of Ukraine to discriminatory on the basis of gen der advertising" [Electronic 2021. Resource access mode: http://fes.kiev.ua/n/cms/25/?tx_news_pi1\%5Bnews $\% 5 \mathrm{D}=722 \& \mathrm{tx}$ news pi $1 \% 5 \mathrm{Bcontr}$ oller $\% 5 \mathrm{D}=$ News\&tx_news pi $1 \% 5$ Baction $\% 5 \mathrm{D}=$ detail\&cHash=39ca1a5469f740b4db2c0485cd8ae403

6. Advertising revolution: now sexism has no place on boards and in commercials [Electronic resource] . 2021. Resource access mode: https://www.ukrinform.ua/rubric-society/3325358-reklamna-revolucia-teperseksizmu-ne-misce-na-bordah-i-v-rolikah.html

1. yana.khodachuk@oa.edu.ua,

2.YYuliia.maslova@oa.edu.ua 